\title{
Influence of a mixture of cinnamaldehyde and garlic oil on rumen fermentation, feeding behavior and performance of lactating dairy cows
}

\author{
M. Blanch, M.D. Carro, M.J. Ranilla, A. Viso, M. Vázquez-Añón, A. Bach
}

\begin{abstract}
A B S T R A C T
Two experiments were conducted to study the effects of Next Enhance ${ }^{\circledR} 300$ (NE300; cinnamaldehyde and garlic oil encapsulated product) on rumen fermentation and milk production of dairy cows. In experiment 1 , batch cultures of mixed rumen micro-organisms were used to study the effects of increasing concentrations of $\operatorname{NE300}(0,200,300$, and $400 \mathrm{mg} / \mathrm{L}$ ) on ruminal fermentation in $24 \mathrm{~h}$ in vitro incubations. All tested doses decreased $(\mathrm{P}<0.05)$ methane production, but the dose of $400 \mathrm{mg} / \mathrm{L}$ also reduced the production of volatile fatty acid (VFA). The addition of NE300 at $300 \mathrm{mg} / \mathrm{L}$ produced the most beneficial effects, reducing methane production, acetate proportion, and ammonia-N concentration, and increasing propionate proportion compared with CON, without affecting total VFA production. These results would indicate a potentially greater supply of energy for the host animal. In experiment 2 , sixteen lactating dairy cows (8 rumen-cannulated) participated in a switch-back design with three 4-wk periods and 2 treatments: control (CON, unsupplemented) and NE300 (300 mg NE300/cow/d). Milk yield response was affected by a 3-way interaction among treatment, parity, and days on treatment; after $15 \mathrm{~d}$ on treatment, multiparous cows on NE300 produced more milk (approximately additional $3 \mathrm{~kg} / \mathrm{d}$ ) than multiparous cows on CON. Total rumen VFA concentrations tended $(\mathrm{P}=0.06)$ to be greater in NE300 than in CON when rumen fermentation kinetics were evaluated at the end of each period (day 28). It is concluded that NE300 modifies ruminal fermentation resulting in increased milk yield in multiparous lactating dairy cows after $15 \mathrm{~d}$ of adaptation.
\end{abstract}

Abbreviations: ADFom, acid detergent fiber; AFOM, amount of organic matter apparently fermented; AOAC, Association of Official Analytical Chemists; BCRM, batch cultures of mixed ruminal microorganisms; BW, body weight; CIN, cinnamaldehyde; CON, control; CP, crude protein; DIM, days in milk; DM, dry matter; DMI, dry matter intake; EO, essential oils; GAR, garlic oil; MUN, milk urea nitrogen; aNDFom, neutral detergent fiber; NE300, Next Enhance ${ }^{\circledR}$ 300; SCC, somatic cell counts; SD, standard deviation; TMR, total mixed ration; VFA, volatile fatty acids. 


\section{Introduction}

Essential oils (EO) are naturally occurring secondary metabolites and volatile components that can have antimicrobial activities against a wide variety of microorganisms including bacteria, protozoa, fungi, and viruses (Chao et al., 2000). There have several in vitro (McIntosh et al., 2003; Castillejos et al., 2005; Mateos et al., 2013) or in situ (Benchaar et al., 2003; Molero et al., 2004; Newbold et al., 2004) studies to evalute the potential of EO to manipulate rumen microbial fermentation. In contrast, only a few studies have been conducted in vivo (Tager and Krause, 2011; Flores et al., 2013; Wall et al., 2014), and the response of EO in vivo has been highly variable.

Cinnamaldehyde (CIN) and garlic oil (GAR) are two of the most investigated EO in the literature and their antimicrobial properties and potential to modify ruminal fermentation have been widely demonstrated, although most of the research available has been conducted in vitro (Calsamiglia et al., 2007; Mateos et al., 2013). These two EO tested separately in vitro showed potential as ruminal modifiers in a dose-dependent manner, affecting mainly the volatile fatty acids (VFA) profile and methane production (in the case of GAR), with more inconsistent effects on rumen $\mathrm{N}$ metabolism (Calsamiglia et al., 2007; Benchaar et al., 2008a). Three separate studies conducted in vivo reported no effects on ruminal fermentation when supplementing $1 \mathrm{~g} \mathrm{CIN/cow/d} \mathrm{(Benchaar} \mathrm{et} \mathrm{al.,} \mathrm{2008b),} 5 \mathrm{~g} \mathrm{GAR/cow/d} \mathrm{(Yang} \mathrm{et} \mathrm{al.,} \mathrm{2007),} \mathrm{or} \mathrm{3.3} \mathrm{g} \mathrm{diallyl} \mathrm{disulfide/cow/d} \mathrm{(one}$ of the main compounds of GAR; van Zijderveld et al., 2011). However, the possible effects of a combination of CIN and GAR on rumen fermentation have not yet been tested in dairy cattle, although Cavini et al. (2009) studied the combination of cinnamaldehyde, garlic and eugenol, and reported a synergy among the 3 extracts for the reduction of methane in vitro.

Limited in vivo research has been conducted in dairy cows using CIN or GAR as active ingredients (Benchaar et al., 2008b; Busquet et al., 2003; Yang et al., 2007) to evaluate their effect on performance; but no change in milk yield was observed in any case. To our knowledge, only three previous studies have investigated effects of this blend of CIN and GAR in vivo: Kamel et al. (2009) reported the effect on milk yield and composition, and Serbester et al. (2012) focused the response on serum metabolites, hormone concentrations, and pregnancy rate of early lactating dairy cows under heat exposure. Kamel et al. (2009) reported that dairy cows receiving daily a mixture of $129 \mathrm{mg}$ of CIN and $15 \mathrm{mg}$ of GAR had lower milk urea nitrogen (MUN) and somatic cell counts (SCC) than those unsupplemented, but there were no differences in milk yield and composition. Guozhong et al. (2010) tested the same concentration of active ingredients, and reported a reduction in MUN and SCC; although in this case an increase in milk yield was also observed with the EO group compared with control (37.4 vs. $35.7 \mathrm{~kg} / \mathrm{d}$ ). Serbester et al. (2012) used the same dose of CIN and GAR in dairy cows under heat exposure and reported no effects on MUN or SCC, but supplemented cows had greater serum insulin concentrations and lower total cholesterol concentrations compared with the unsuplemented cows. However, none of these studies investigated the effects of the blend of CIN and GAR on feeding behavior and rumen fermentation. Therefore, the objective of this study was to determine the effect of a commercially-available product based on CIN and GAR on rumen fermentation, feeding behavior and milk production in dairy cows. In addition, an in vitro experiment was conducted to further delineate the ruminal effect of CIN and GAR. Our hypothesis was that feeding this additive would modify ruminal fermentation profile (VFA profile and methane) which could in turn result in increased milk yield.

\section{Materials and methods}

All animals in this study were managed in accordance with the Spanish guidelines for experimental animal protection (Royal Decree 53/2013 of February 1 st on the protection of animals used for experimentation or other scientific purposes) in line with the European Directive for the Protection of animals used for scientific purposes (Directive 2010/63/UE). The procedures of experiment 1 were approved by the Institutional Animal Care and Use Committee of the University of León. Cows from experiment 2 were maintained and handled under the supervision of the Animal Care Committee of the Institut de Recerca i Tecnologia Agroalimentàries.

The feed additive Next Enhance ${ }^{\circledR} 300$ (NE300, Novus International Inc., St Charles, MO) was the target of this study, which is an encapsulated product based on CIN (430 g/ kg) and GAR $(70 \mathrm{~g} / \mathrm{kg})$.

\subsection{Experiment 1}

\subsubsection{Animals and in vitro incubations}

Four adult rumen-cannulated Merino sheep $(58.3 \pm 3.27 \mathrm{~kg}$ BW) were used as rumen fluid donors to conduct in vitro incubations. Animals were placed in individual pens with free access to water and a mineral-vitamin mixture. Sheep were fed a 60:40 mixed diet of alfalfa hay and a concentrate at $52 \mathrm{~g} \mathrm{DM} / \mathrm{kg} \mathrm{BW}^{0.75}$ distributed in two equal meals offered at 0800 and $2000 \mathrm{~h}$. Concentrate was composed of barley, corn, soybean meal, full fat soya, lupin, oat, fullfat soybean, calcium carbonate, sugarcane molasses, salt, wheat middlings, dicalcium phosphate, and mineral-vitamin premix in proportions of 392, 192, 142, 120, 75, 30, 13, 10.2, 7, 4.6, 4.2, 10 and $4 \mathrm{~g}$ per $\mathrm{kg}$, respectively. The complete diet contained 930, 174, 350, 213 and $48.9 \mathrm{~g}$ of organic matter, crude protein (CP), aNDFom, ADFom, and acid detergent lignin per kg of DM, respectively.

Batch cultures of mixed ruminal microorganisms (BCRM) were used to test the effects of NE300. Samples of the diet fed to sheep were used as substrates for the in vitro fermentations. Alfalfa hay and concentrate were ground through a 1-mm screen and mixed in the corresponding proportion. Four batches of substrate were prepared and mixed with the additive to achieve final concentrations of $0,200,300$ and $400 \mathrm{mg}$ of additive per L of incubation medium. Samples (300 mg of DM) of each 
substrate were weighed into 120 -mL serum bottles. Two bottles per experimental treatment were incubated, and 2 additional bottles without substrate (blanks) were included to correct the gas production values for gas release from endogenous substrates. Rumen content from each donor sheep was obtained immediately before the afternoon feeding, strained through 4 layers of cheesecloth into thermos flasks pre-heated at $39^{\circ} \mathrm{C}$ and immediately transferred to the laboratory. The samples were mixed in equal proportions and the resulting fluid was mixed with the buffer solution of Goering and Van Soest (1970 in a $1: 4 \mathrm{ratio}(\mathrm{vol} / \mathrm{vol})$ at $39^{\circ} \mathrm{C}$ under continuous flushing with $\mathrm{CO}_{2}$. Thirty milliliters of the mixture were added into each bottle and sealed with rubber stoppers and aluminum caps and incubated at $39^{\circ} \mathrm{C}$ for $24 \mathrm{~h}$. Total gas production was measured using a pressure transducer (HD2304.0 pressure gauge, DELTA OHM, Italy) and a calibrated syringe. A gas sample $(10 \mathrm{~mL})$ was removed from each bottle and stored in a vacuum tube (Terumo Europe N.V., Leuven, Belgium) for analysis of $\mathrm{CH}_{4}$. Bottles were then uncapped and the $\mathrm{pH}$ was measured immediately with a pH meter (Crison Basic 20, Crisson Instruments, Barcelona, Spain). Three $\mathrm{mL}$ of content was added to $3 \mathrm{~mL}$ of deproteinising solution ( $20 \mathrm{~g}$ of metaphosphoric acid and $0.6 \mathrm{~g}$ of methylvaleric acid per $\mathrm{L}$ ) for VFA determination and $4 \mathrm{~mL}$ were added to $4 \mathrm{~mL} 0.2 \mathrm{M} \mathrm{HCl}$ for $\mathrm{NH}_{3}-\mathrm{N}$ analysis. Samples were frozen at $-20^{\circ} \mathrm{C}$ until analysis. The incubation was repeated on 4 non-consecutive days.

\subsubsection{Calculations and statistical analyses}

The amounts of VFA produced in each culture were calculated by subtracting the amount present initially in the incubation medium from that determined at the end of the incubation period. The volume of gas produced was corrected for temperature $\left(273^{\circ} \mathrm{K} ; 0^{\circ} \mathrm{C}\right)$ and pressure $(1 \mathrm{~atm})$ and the amount of $\mathrm{CH}_{4}$ was calculated by multiplying the gas produced by the concentration of $\mathrm{CH}_{4}$ in the analyzed sample. Recovery of hydrogen in each bottle was estimated from net productions of acetate, propionate, butyrate, valerate, and methane (Demeyer, 1991), and the amount of organic matter apparently fermented (AFOM) was estimated from VFA production using the equation proposed by Demeyer and Van Nevel (1975). Values measured of the 2 bottles incubated for each treatment within each run were averaged before conducting statistical analysis (4 values per experimental treatment).

Data were analyzed using a mixed-effects model in SAS (SAS Inst. Inc., Cary, NC, USA) accounting for the fixed effect of the four concentrations of additive $(0,200,300$ and $400 \mathrm{mg} / \mathrm{L})$ and the random effect of inoculum (donor sheep). Significance was declared at $\mathrm{P}<0.05$ and trends at $\mathrm{P}<0.10$. A Dunnett's test was performed to compare treatments with control.

\subsection{Experiment 2}

\subsubsection{Animals and experimental design}

Sixteen lactating Holstein dairy cows, eight of which were fitted with ruminal cannulas (\#1C 4" cannula; Bar Diamond Inc., Idaho, USA) participated in this study. At the beginning of the trial the cows averaged (mean \pm SD) $668 \pm 18.2 \mathrm{~kg}$ BW, $28.6 \pm 6.25 \mathrm{~kg}$ of milk yield, $199 \pm 13.2$ days in milk (DIM), and the average lactation number was $2.2 \pm 1.3$ ( 8 primiparous, and 8 multiparous). All cows were kept at the experimental research farm of the Institut de Recerca i Tecnologia Agroalimentàries in Monells (Girona, Spain) in loose housing conditions using straw as bedding. The animals were blocked for parity, DIM, and level of milk production. Treatments consisted on a total mixed ration (TMR) containing either no additive (control, CON) or supplemented with NE300 at a rate estimated to provide daily $300 \mathrm{mg}$ of NE300 per cow (NE300). Animals were enrolled in a switch-back experiment with three 4-week periods and 2 treatments. Basically half of the cows were exposed to CON for 4 weeks, then to NE300 for 4 weeks, and lastly to CON again for additional 4 weeks, whereas the other half of the cows were exposed to NE300 for 4 weeks, then to CON for 4 weeks, and lastly to NE300 again for additional 4 weeks. The ingredient and chemical composition of the experimental rations is given in Table 1 . Cows were fed ad libitum at 0830 and $1600 \mathrm{~h}$ and had free access to water.

\subsubsection{Measurements and sample collection}

Individual feed consumption was continuously monitored throughout the study using a computerized system (Bach et al., 2004). Grab samples from each ration were collected every other day and frozen. These samples were composited fortnightly within period and analyzed for DM and chemical composition. Individual milk production was recorded at each milking. In addition, individual milk composition (fat, protein, lactose, MUN, and SCC) was determined at both AM and PM milkings on days $0,7,14,21,27$, and 28 of each experimental period at an official laboratory (ALLIC, Cabrils, Spain).

Rumen cannulated animals were used to collect rumen samples on days $0,7,14$, and 21 at $4 \mathrm{~h}$ after the morning feeding to determine concentration of VFA and $\mathrm{NH}_{3}-\mathrm{N}$, and on day 28 , rumen samples were collected at $0,2,4,6$, and $8 \mathrm{~h}$ after the morning feeding to evaluate kinetics of VFA and $\mathrm{NH}_{3}-\mathrm{N}$ concentrations in the rumen. Samples were frozen at $-20^{\circ} \mathrm{C}$ until analysis. During the last 2 weeks of each period, two indwelling rumen $\mathrm{pH}$ probes (Bach et al., 2007) were placed in the rumen of 2 cows, one from CON and one from NE300 treatment for 3 consecutive days ( 4 cows each week), in a manner that all rumen-cannulated cows were monitored for rumen $\mathrm{pH}$ once every period. Lastly, coinciding with rumen samplings, all rumen-cannulated cows were blood-sampled to determine glucose and insulin concentrations.

\subsubsection{Statistical analyses}

For milk composition, both AM and PM values were averaged within day and cow and a single value for each day was then used in the statistical model. Data regarding feed intake, milk yield, rumen and blood parameters were analyzed using 
Table 1

Ingredient and nutrient composition of the control (CON) and the treatment (NE300) rations in experiment 2.

\begin{tabular}{|c|c|c|}
\hline Item & $\mathrm{CON}$ & NE300 \\
\hline \multicolumn{3}{|l|}{ Ingredients (g/kg) } \\
\hline Alfalfa hay & 100.2 & 100.2 \\
\hline Sorghum silage & 115.4 & 115.4 \\
\hline Corn silage & 510,2 & 510.2 \\
\hline Barley & 57.7 & 57.7 \\
\hline Corn & 74,8 & 74.8 \\
\hline Wheat & 11.5 & 11.5 \\
\hline Soybean meal & 80.8 & 80.8 \\
\hline Calcium carbonate & 1.85 & 1.85 \\
\hline Magnesium oxide & 0.69 & 0.69 \\
\hline Salt & 0.46 & 0.46 \\
\hline Mineral vitamin premix ${ }^{\mathrm{a}}$ & 0.23 & 0.23 \\
\hline Corn premix ${ }^{\mathrm{b}}$ & 46.2 & 46.2 \\
\hline \multicolumn{3}{|l|}{ Nutrients } \\
\hline Crude protein (g/kg) & 162 & 161 \\
\hline Net energy (Mcal/kg) & 1.67 & 1.67 \\
\hline aNDFom $(\mathrm{g} / \mathrm{kg})$ & 339 & 334 \\
\hline aADFom (g/kg) & 193 & 192 \\
\hline Non-fiber carbohydrates (g/kg) & 422 & 429 \\
\hline Ether extract $(\mathrm{g} / \mathrm{kg})$ & 30.2 & 29.5 \\
\hline Ash (g/kg) & 46.6 & 46.1 \\
\hline
\end{tabular}

a Vitamin mineral premix composition: $3750 \mathrm{kIU} / \mathrm{kg}$ of vitamin A, $750 \mathrm{kIU} / \mathrm{kg}$ of vitamin D, $2.5 \mathrm{mg} / \mathrm{kg}$ of vitamin E, $2.5 \mathrm{~g} / \mathrm{kg}$ of Fe, $12.5 \mathrm{~g} / \mathrm{kg}$ of Zn, $1.25 \mathrm{~g} / \mathrm{kg}$ of $\mathrm{Cu}, 10 \mathrm{~g} / \mathrm{kg}$ of $\mathrm{Mn}, 0.1 \mathrm{~g} / \mathrm{kg}$ of $\mathrm{Co}$, and $0.4 \mathrm{~g} / \mathrm{kg}$ of $\mathrm{I}$.

b Denotes that premix contained $150 \mathrm{~g}$ of Next Enhance 300 per MT of corn.

a mixed-effects model with animal within period and treatment as a random effect, and sequence (whether CON-NE300CON or NE300-CON-NE300), period, treatment, parity, time, and the interactions between treatment and period, treatment and time, treatment and parity, and treatment and parity and time as fixed effects. Time entered the model as a repeated measure using each cow within period and treatment as subject. The variance-covariance structure used was compound symmetry. When the triple interaction was not significant, it was removed from the model. As in Experiment 1, significance was declared at $\mathrm{P}<0.05$ and trends at $\mathrm{P}<0.10$.

\subsection{Chemical analyses}

Dry matter (ID 934.01), ash (ID 942.05) and N (ID 984.13) content were determined according to the Association of Official Analytical Chemists (AOAC, 1999). aNDFom, ADFom and acid detergent lignin analyses were performed out according to Van Soest et al. (1991) using an ANKOM220 Fibre Analyzer unit (ANKOM Technology Corporation, Fairport, NY, USA). Sodium sulfite and heat-stable amylase were used in the sequential analysis of aNDFom and ADFom, and they were expressed exclusive of residual ash. Ether extract was determined following the AOAC method (920.39) with petroleum ether for distillation instead of diethyl ether (AOAC, 1990).

Analysis of $\mathrm{CH}_{4}$ in the in vitro experiment was carried out following the procedure of Martínez et al. (2010) using a gas chromatograph (Shimadzu GC 14B; Shimadzu Europa GmbH, Duisburg, Germany) equipped with a flame ionization detector and a column packed with Carboxen 1000 (Supelco, Madrid, Spain). Samples for VFA analysis were prepared and analyzed as described by Jouany (1982) using a gas chromatograph (model 6890, Hewlett Packard, Pablo Alto, CA, USA) provided with a polythylene glycol nitroterephthalic acid-treated capillary column (BP21, SGE, Europe Ltd., Buckinghamshire, UK). Ammonia $\mathrm{N}$ concentration in the rumen liquid was analyzed by spectrophotometry (Libra S21, Biochrom Analytical Instruments, Cambridge, UK) as described by Chaney and Marbach (1962).

Serum concentrations of glucose were analyzed by the enzymatic HK/G-6-PDH method (Burrin and Price, 1985) and those of insulin by ELISA using a commercial kit (Mercodia, Uppsala, Sweden).

\section{Results}

\subsection{Experiment 1}

The effects of increasing doses of NE300 on in vitro rumen fermentation are shown in Table 2. Providing $200 \mathrm{mg} / \mathrm{L}$ of NE300 had minimal effects on rumen VFA production and $\mathrm{NH}_{3}-\mathrm{N}$ concentrations, as only a reduction $(\mathrm{P}<00.05)$ of $\mathrm{CH}_{4} \mathrm{pro}^{-}$ duction and acetate/propionate ratio was detected compared with CON. The supply of NE300 at $300 \mathrm{mg} / \mathrm{L}$ reduced $\mathrm{NH}_{3}-\mathrm{N}$ concentrations by $9 \%(\mathrm{P}<0.05), \mathrm{CH}_{4}$ production by $68 \%(\mathrm{P}<0.001)$ and acetate proportion by $8 \%(\mathrm{P}<0.01)$ and increased propionate proportion by $18 \%(\mathrm{P}<0.01)$ without affecting total VFA production compared to CON. However, NE300 at $400 \mathrm{mg} / \mathrm{L}$ decreased $(\mathrm{P}<0.05)$ both VFA production and the amount of AFOM, indicating negative effects on rumen fermentation. 
Table 2

Effects of different doses of Next Enhance ${ }^{\circledR}$ (NE300) on fermentation parameters after 24 h of incubation of a $60: 40$ alfalfa hay:concentrate diet (300 mg) in batch cultures of rumen microorganisms $(n=4)$.

\begin{tabular}{|c|c|c|c|c|c|c|}
\hline & \multicolumn{6}{|c|}{ Dose NE300 (mg/L) ${ }^{\mathrm{a}}$} \\
\hline & 0 (Control) & 200 & 300 & 400 & SEM $^{\mathrm{b}}$ & P-value \\
\hline $\mathrm{pH}$ & 6.74 & 6.74 & 6.74 & 6.74 & 0.014 & 0.998 \\
\hline Ammonia-N (mg/L) & 297 & 284 & $270^{*}$ & $269^{*}$ & 7.14 & 0.069 \\
\hline Gas $(\mathrm{mL})$ & 72.3 & 71.2 & 68.1 & $61.2^{* *}$ & 1.70 & 0.005 \\
\hline Methane ( $\mu \mathrm{mol})$ & 476 & $210^{* * *}$ & $151^{* * *}$ & $91.6^{* * *}$ & 20.7 & $<0.001$ \\
\hline Volatile fatty acid (VFA) production ( $\mu \mathrm{mol})$ & 1706 & 1785 & 1730 & $1533^{*}$ & 50.3 & 0.031 \\
\hline \multicolumn{7}{|l|}{ Molar proportions (mol/100 mol) } \\
\hline Acetate & 61.7 & 59.8 & $56.5^{* *}$ & $54.0^{* * *}$ & 1.13 & 0.005 \\
\hline Propionate & 22.9 & 24.8 & $27.1^{* *}$ & $26.9^{* *}$ & 0.78 & 0.014 \\
\hline Butyrate & 10.5 & 10.6 & 11.5 & $13.5^{\dagger}$ & 1.08 & 0.237 \\
\hline Isobutyrate & 0.75 & 0.58 & 0.50 & 0.66 & 0.085 & 0.256 \\
\hline Isovalerate & 1.86 & 1.83 & 1.67 & $1.56^{*}$ & 0.084 & 0.099 \\
\hline Valerate & 2.32 & 2.44 & 2.74 & $3.46^{* *}$ & 0.178 & 0.006 \\
\hline Acetate:Propionate (mol/mol) & 2.69 & $2.42^{* *}$ & $2.08^{* * *}$ & $2.01^{* * *}$ & 0.080 & $<0.001$ \\
\hline Methane/VFA $(\mu \mathrm{mol} / \mu \mathrm{mol})$ & 0.279 & $0.123^{* * *}$ & $0.090^{* * *}$ & $0.059^{* * *}$ & 0.0138 & $<0.001$ \\
\hline Hydrogen recovery $(\mathrm{mol} / 100 \mathrm{~mol})$ & 98.6 & $68.9^{* * *}$ & $65.8^{* * *}$ & $61.6^{* * *}$ & 3.30 & $<0.001$ \\
\hline Apparently fermented organic matter (AFOM; mg) & 146 & 153 & 149 & $133^{*}$ & 3.42 & 0.013 \\
\hline \multicolumn{7}{|l|}{ a Different from Control by Dunnett test. } \\
\hline \multicolumn{7}{|l|}{ b SEM: standard error of the mean. } \\
\hline \multicolumn{7}{|l|}{$\dagger \mathrm{P}<0.10$} \\
\hline \multicolumn{7}{|l|}{${ }^{*} \mathrm{P}<0.05$} \\
\hline \multicolumn{7}{|l|}{${ }^{* *} \mathrm{P}<0.01$} \\
\hline${ }^{* * *} \quad \mathrm{P}<0.001$ & & & & & & \\
\hline
\end{tabular}

\subsection{Experiment 2}

Period and sequence had no effect $(\mathrm{P}>0.05)$ on any dependent variable measured, except for blood glucose concentration and rumen concentrations of total VFA and valerate (data not shown). Feed intake and feeding behavior data are shown in Table 3. None of the intake-related parameters were affected by any of the variables considered in the model except for the time devoted to eat, that was lower $(P=0.03)$ in NE300 than in CON cows. There was an interaction between treatment and day of study illustrating that time devoted to eat was lower $(\mathrm{P}=0.02)$ in NE300 cows compared with CON cows during the initial (7-10) and last ( $>25$ ) days of study (Fig. 1 ).

Milk yield and composition are shown in Table 3. Overall there were no differences in milk yield between treatments; however, there was a 3-way interaction ( $\mathrm{P}=0.001)$ among treatment, parity, and days on treatment, which resulted in increased milk yield (about additional $3 \mathrm{~kg} / \mathrm{d}$ ) in multiparous cows on NE300 (32.5 $\pm 1.17 \mathrm{~kg} / \mathrm{d}$ ) compared with multiparous cows (29.7 $\pm 1.17 \mathrm{~kg} / \mathrm{d}$ ) on CON (Fig. 2) after 2 weeks on treatment. Similarly, milk fat content was not affected by treatment; however, we observed an effect of parity. Overall, milk fat content was lower $(P=0.03)$ in primiparous $(34.6 \pm 1.1 \mathrm{~g} / \mathrm{kg})$ than in multiparous $(38.8 \pm 1.1 \mathrm{~g} / \mathrm{kg})$ cows. Similarly, milk protein content was not affected by treatment, but there was a parity effect. Milk protein content was lower $(\mathrm{P}=0.008)$ in primiparous $(32.5 \pm 0.5 \mathrm{~g} / \mathrm{kg})$ than in multiparous $(34.5 \pm 0.5 \mathrm{~g} / \mathrm{kg}) \mathrm{cows}$. Milk lactose and urea concentrations were not affected by EO. Milk somatic cell counts (SCC) were low throughout the study, and primiparous cows had lower $(\mathrm{P}<0.001)$ values $(51,000$ cells $/ \mathrm{ml})$ than multiparous $(185,000$ cells $/ \mathrm{ml})$ cows.

Table 3

Feed intake and feeding behavior and milk production and composition as affected by treatment (CON: Control, NE300: Next Enhance ${ }^{\circledR}$ 300), parity, and days on treatment.

\begin{tabular}{|c|c|c|c|c|c|c|c|c|c|}
\hline \multirow[b]{2}{*}{ Item } & \multicolumn{2}{|c|}{ Treatment } & \multirow[b]{2}{*}{ SEM } & \multicolumn{6}{|c|}{ P-value $^{a}$} \\
\hline & $\mathrm{CON}$ & NE300 & & $\mathrm{T}$ & $\mathrm{D}$ & $\mathrm{P}$ & $\mathrm{T} \times \mathrm{D}$ & $\mathrm{T} \times \mathrm{P}$ & $\mathrm{T} \times \mathrm{D} \times \mathrm{P}$ \\
\hline DMI (kg/d) & 22.5 & 21.5 & 0.59 & 0.22 & 0.002 & 0.12 & 0.21 & 0.46 & - \\
\hline Time eating $(\mathrm{min} / \mathrm{d})$ & 172 & 164 & 2.5 & 0.03 & 0.26 & 0.28 & 0.02 & 0.77 & - \\
\hline Eating rate ( $\mathrm{g}$ of $\mathrm{DM} / \mathrm{min})$ & 140 & 134 & 3.56 & 0.97 & 0.15 & 0.02 & 0.28 & 0.37 & - \\
\hline Feed efficiency & 1.33 & 1.46 & 0.05 & 0.11 & 0.18 & 0.89 & 0.30 & 0.89 & - \\
\hline Milk yield (kg/d) & 29.4 & 30.0 & 1.17 & 0.73 & $<0.001$ & 0.14 & 0.01 & 0.45 & 0.001 \\
\hline Fat $(\mathrm{g} / \mathrm{kg})$ & 36.6 & 35.9 & 1.0 & 0.61 & $<0.001$ & 0.03 & 0.08 & 0.87 & - \\
\hline Protein $(\mathrm{g} / \mathrm{kg})$ & 33.6 & 33.3 & 0.4 & 0.73 & 0.003 & 0.008 & 0.06 & 0.40 & - \\
\hline Lactose $(\mathrm{g} / \mathrm{kg})$ & 48.9 & 49.1 & 0.2 & 0.48 & 0.002 & $<0.001$ & 0.49 & 0.66 & 0.02 \\
\hline Urea, (mg/L) & 194 & 185 & 7.18 & 0.35 & 0.08 & 0.56 & 0.80 & 0.15 & - \\
\hline Somatic cell count $\left(10^{3}\right.$ cells $\left./ \mathrm{mL}^{\mathrm{b}}\right)$ & 109 & 107 & 0.61 & 0.91 & 0.17 & $<0.001$ & 0.29 & 0.30 & - \\
\hline
\end{tabular}

a T: Treatment; D: days; P: Parity: TxD: interaction between treatment and days; TxP: interaction between treatment and parity; TxDxP: interaction between treatment, days, and parity.

b Values for Somatic cell count were root-squared transformed to reach a normal distribution. Depicted values for CON and NE300 correspond to back-transformed data, whereas SEM corresponds to root-squared values. 


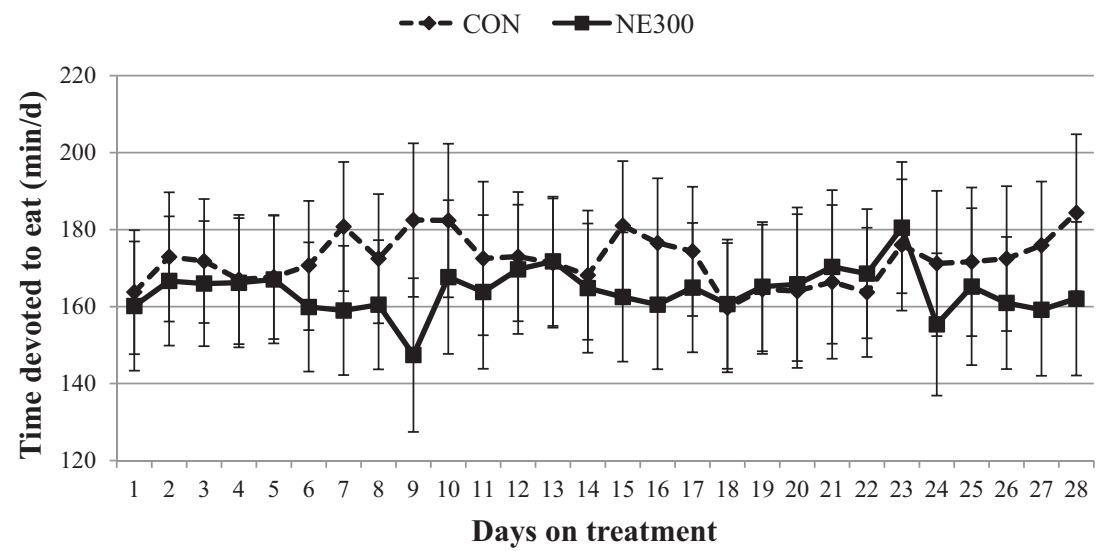

Fig. 1. Evolution of the time devoted to eat (min/d) as affected by treatment (CON: Control, NE300: Next Enhance $\left.{ }^{\circledR} 300\right)$ over the experimental period [Error bars represent standard errors].

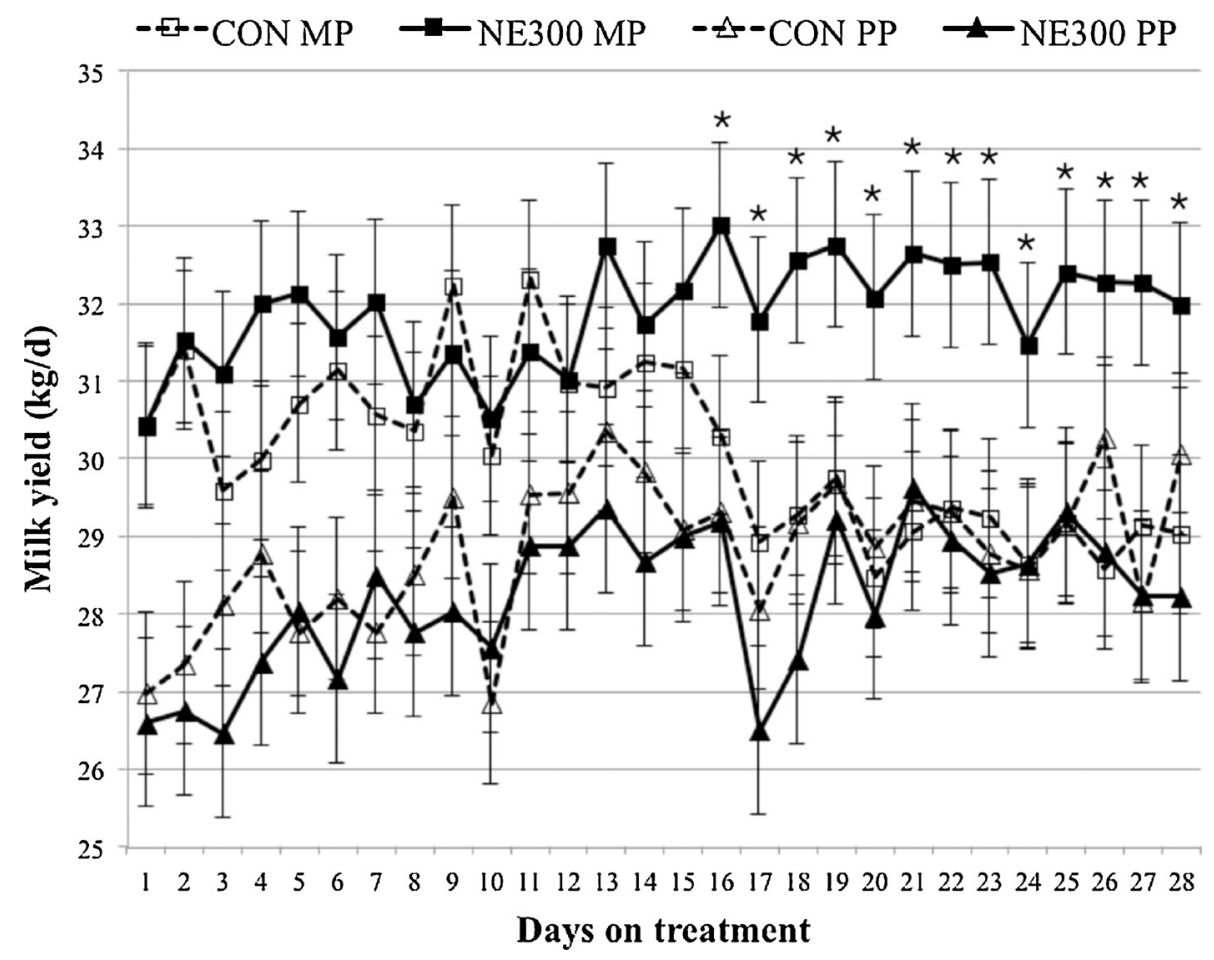

Fig. 2. Milk production (kg/d) as affected by treatment (CON: Control, NE300: Next Enhance $\left.{ }^{\circledR} 300\right)$, parity (MP: multiparous; PP: Primiparous), and days on treatment [Error bars represent standard errors]. For each time point asterisks depict differences $(\mathrm{P}<0.05)$ between multiparous cows on Control and on NE300 treatment.

Rumen fermentation data are presented in Tables 4 and 5. Overall, no changes in total rumen VFA concentrations, VFA profile, and $\mathrm{NH}_{3}-\mathrm{N}$ were observed between treatments (Table 4). However, total rumen VFA concentrations tended $(\mathrm{P}=0.06)$ to be greater in NE300 compared with CON when rumen fermentation kinetics was evaluated at the end of each period (day 28; Fig. 3). Furthermore, there was a tendency $(P=0.09)$ for an interaction between treatment and hour (Table 5). The evolution of total rumen VFA concentration is represented in Fig. 3. There were no differences between treatments either in rumen $\mathrm{pH}(\mathrm{P}=0.97 ; 6.37$ and 6.37 for $\mathrm{CON}$ and NE300, respectively $)$ or the daily time elapsed with $\mathrm{pH}<5.6(\mathrm{P}=0.97 ; 88.9$ and $91.0 \mathrm{~min} / \mathrm{d}$ for CON and NE300, respectively).

As shown in Table 6, supplementation of NE300 had no effect on blood insulin $(P=0.56)$ or glucose concentrations $(\mathrm{P}=0.57)$. Likewise, there were no differences between primiparous or multiparous cows in blood glucose, but multiparous cows had greater $(P<0.05)$ blood insulin values than primiparous $(31.7 v s .24 .9 \mu \mathrm{U} / \mathrm{mL}$, respectively). The interaction between treatment and parity was not significant either for any of these blood parameters. 
Table 4

Rumen fermentation as affected by treatment (CON: Control, NE300: Next Enhance $\left.{ }^{\circledR} 300\right)$, parity, and days on treatment.

\begin{tabular}{|c|c|c|c|c|c|c|c|c|}
\hline \multirow[b]{2}{*}{ Item } & \multicolumn{2}{|c|}{ Treatment } & \multirow[b]{2}{*}{ SEM } & \multicolumn{5}{|c|}{ P-value ${ }^{a}$} \\
\hline & CON & NE300 & & $\mathrm{T}$ & $\mathrm{D}$ & $\mathrm{P}$ & $\mathrm{T} \times \mathrm{D}$ & $\mathrm{T} \times \mathrm{P}$ \\
\hline Total VFA, mmol/L & 119 & 118 & 4.34 & 0.88 & 0.02 & 0.85 & 0.25 & 0.51 \\
\hline \multicolumn{9}{|c|}{ Molar proportions (mol/100 mol) } \\
\hline Acetate & 59.3 & 59.2 & 1.12 & 0.93 & 0.01 & 0.88 & 0.99 & 0.19 \\
\hline Propionate & 23.2 & 23.5 & 1.28 & 0.89 & 0.02 & 0.31 & 0.60 & 0.15 \\
\hline Butyrate & 12.4 & 12.6 & 0.46 & 0.77 & 0.31 & 0.001 & 0.87 & 0.43 \\
\hline Isobutyrate & 1.10 & 1.09 & 0.05 & 0.88 & 0.17 & 0.07 & 0.40 & 0.38 \\
\hline Valerate & 1.92 & 1.78 & 0.11 & 0.51 & 0.007 & 0.14 & 0.71 & 0.35 \\
\hline Isovalerate & 1.97 & 1.82 & 0.07 & 0.14 & 0.05 & 0.80 & 0.60 & 0.34 \\
\hline Ammonia $\mathrm{N}, \mathrm{mg} / \mathrm{dL}$ & 9.41 & 9.18 & 0.88 & 0.86 & 0.83 & 0.40 & 0.86 & 0.80 \\
\hline
\end{tabular}

a T: Treatment; D: days; P: Parity: TxD: interaction between treatment and days; TxP: interaction between treatment and parity.

Table 5

Rumen concentration of volatile fatty acids (VFA) during the first $8 \mathrm{~h}$ after the morning feeding as affected by treatment (CON: Control, NE300: Next Enhance $^{\circledR} 300$; measures were taken at the end of each period during day 28).

\begin{tabular}{|c|c|c|c|c|c|c|c|c|c|}
\hline \multirow[b]{2}{*}{ Item } & \multicolumn{2}{|c|}{ Treatment } & \multirow[b]{2}{*}{ SE } & \multicolumn{6}{|c|}{ P-value ${ }^{a}$} \\
\hline & $\mathrm{CON}$ & NE300 & & $\mathrm{T}$ & $\mathrm{H}$ & $\mathrm{P}$ & $\mathrm{T} \times \mathrm{P}$ & $\mathrm{T} \times \mathrm{H}$ & $\mathrm{T} \times \mathrm{H} \times \mathrm{P}$ \\
\hline Rumen VFA, mmol/L & 98.3 & 108.9 & 3.60 & 0.06 & 0.70 & 0.38 & 0.60 & 0.09 & 0.40 \\
\hline \multicolumn{10}{|c|}{ Molar proportions $(\mathrm{mol} / 100 \mathrm{~mol})$} \\
\hline Acetate & 60.4 & 60.7 & 1.23 & 0.88 & $<0.001$ & 0.69 & 0.71 & 0.28 & 0.16 \\
\hline Propionate & 21.7 & 21.3 & 1.38 & 0.80 & $<0.001$ & 0.14 & 0.39 & 0.55 & 0.95 \\
\hline Butyrate & 12.8 & 13.4 & 0.71 & 0.61 & 0.19 & 0.03 & 0.39 & 0.91 & 0.82 \\
\hline Isobutyrate & 1.17 & 1.08 & 0.04 & 0.11 & $<0.001$ & 0.33 & 0.73 & 0.39 & 0.98 \\
\hline Valerate & 1.75 & 1.69 & 0.10 & 0.73 & 0.001 & 0.39 & 0.90 & 0.59 & 0.09 \\
\hline Isovalerate & 2.21 & 2.06 & 0.11 & 0.38 & $<0.001$ & 0.21 & 0.57 & 0.50 & 0.69 \\
\hline
\end{tabular}

${ }^{a} \mathrm{~T}$ : Treatment; H: hour relative to AM feeding; P: Parity; TxP: interaction between treatment and parity; TxH: interaction between treatment and hour relative to AM feeding; TxHxP: interaction between treatment, hour relative to the morning feeding, and parity.

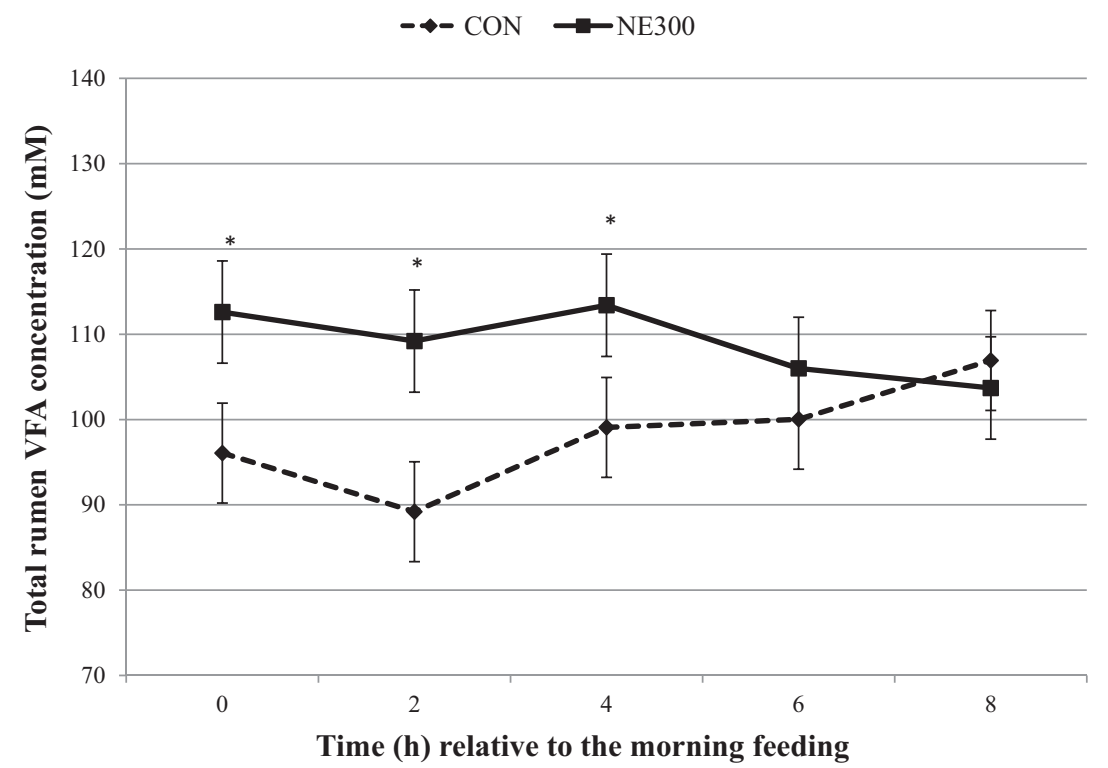

Fig. 3. Total rumen VFA concentration (mM) as affected by treatment (CON: Control, NE300: Next Enhance ${ }^{\circledR} 300$ ) and time relative to the morning feeding [Error bars represent standard errors]. For each time point asterisks depict differences $(\mathrm{P}<0.05)$ between Control and NE300 treatment.

\section{Discussion}

\subsection{Rumen fermentation}

In Experiment 1, the high dose of $400 \mathrm{mg} / \mathrm{L}$ of NE300 (supplying $172 \mathrm{mg}$ of CIN and $28 \mathrm{mg}$ of GAR/L) decreased total VFA production and AFOM compared with CON indicating some inhibition of rumen fermentation. This is in contrast with the results from other studies (Busquet et al., 2005; Macheboeuf et al., 2008; Mateos et al., 2013) in which CIN had no effect on 
Blood insulin and glucose levels as affected by treatment (CON: Control, NE300: Next Enhance $\left.{ }^{\circledR} 300\right)$, parity, and days on treatment.

\begin{tabular}{|c|c|c|c|c|c|c|c|c|c|}
\hline \multirow[b]{2}{*}{ Item } & \multicolumn{2}{|c|}{ Treatment } & \multirow[b]{2}{*}{ SEM } & \multicolumn{6}{|c|}{ P-value ${ }^{a}$} \\
\hline & $\mathrm{CON}$ & NE300 & & $\mathrm{T}$ & $\mathrm{D}$ & $\mathrm{P}$ & $\mathrm{T} \times \mathrm{P}$ & $\mathrm{T} \times \mathrm{D}$ & $\mathrm{T} \times \mathrm{D} \times \mathrm{P}$ \\
\hline Glucose (mg/dL) & 64.8 & 64.0 & 1.26 & 0.57 & 0.29 & 0.78 & 0.68 & 0.81 & 0.84 \\
\hline Insulin $(\mu \mathrm{U} / \mathrm{mL})$ & 27.4 & 29.2 & 2.08 & 0.56 & $<0.001$ & 0.03 & 0.85 & 0.50 & 0.18 \\
\hline Glucose/insulin ratio & 2.88 & 2.51 & 0.26 & 0.35 & $<0.001$ & 0.20 & 0.72 & 0.81 & 0.40 \\
\hline
\end{tabular}

a T: Treatment; D: Days; P: Parity; TxP: interaction between treatment and parity; TxD: interaction between treatment and days; TxDxP: interaction between treatment, days, and parity.

in vitro total VFA production when added up to $312 \mathrm{mg} / \mathrm{L}$. Factors other than the CIN dose may be implicated in the variable response observed in the different studies. Mateos et al. (2013) reported that the effectiveness of CIN and GAR to modify in vitro ruminal fermentation depend on the characteristics of the diet fed to the donor animals. Cardozo et al. (2005) observed that CIN at $300 \mathrm{mg} / \mathrm{L}$ had no effect on in vitro total VFA production when a high-concentrate diet was incubated at $\mathrm{pH} 5.5$, but decreased VFA production by $25 \%$ when the incubation $\mathrm{pH}$ was 7.0 . The supply of NE300 at $300 \mathrm{mg} / \mathrm{L}$ in the current study (using a 60:40 mixed diet of alfalfa hay and a concentrate) decreased $\mathrm{CH}_{4}$ production and increased propionate proportion without affecting total VFA production which would indicate a greater supply of energy for the host animal. In agreement with our results, other in vitro studies using CIN or GAR (individually) reported similar results on rumen fermentation profile in a dose-dependent manner (Busquet et al., 2005, 2006; Mateos et al., 2013). Several in vitro studies demonstrated that GAR reduced the $\mathrm{CH}_{4}$ production (Soliva et al., 2011; Kim et al., 2012; Mateos et al., 2013), although no response was observed by others (Kongmun et al., 2010). The variable conditions in the different in vitro studies (i.e., EO used, technique, substrate, doses of active ingredients, etc.) may help to explain the variability in the results.

On the other hand, response of supplementing CIN and GAR separately on rumen $\mathrm{N}$ metabolism has been more inconsistent among studies. Although some studies reported changes in rumen N metabolism (Cardozo et al., 2004; Mateos et al., 2013), others found no effects (Busquet et al., 2005). In the present study NE300 at 300 and $400 \mathrm{mg} / \mathrm{L}$ reduced rumen $\mathrm{NH}_{3}-\mathrm{N}$ concentrations. This is consistent with the reduction in Prevotella spp., a group of bacteria known to be involved in deamination, observed by Ferme et al. (2004) when an in vitro rumen simulation system was supplemented with CIN or GAR.

In contrast with the in vitro results, no major changes in rumen fermentation patterns were observed in vivo, and only total VFA rumen concentrations tended to be greater in NE300 compared with CON when daily rumen fermentation kinetics was evaluated at the end of each period (Table 5). A meta-analysis conducted by Hristov et al. (2012) reported that results obtained in vitro are not always representative of what occurs in vivo because many important differences exist between the two systems that can influence the digestive processes (i.e., lack of absorption, differences in fluid and particle dilution rates, feed intake relative to rumen volume, homogeneity of the compartment, etc.). Moreover, the doses used for in vitro experiments are usually much greater than what is administered in vivo (Calsamiglia et al., 2007). In fact, the dose used in vivo in the present study was about $1.29 \mathrm{mg}$ of CIN and $0.21 \mathrm{mg}$ of GAR per L (calculated for a daily intake of $300 \mathrm{mg}$ of NE300 and a rumen volume of $100 \mathrm{~L}$ ), which is 67,100 and 133 times lower than the 200, 300, and $400 \mathrm{mg} / \mathrm{L}$ doses used in the in vitro experiment, respectively. In vivo research with individual constituents of NE300 is limited and no rumen effect has been reported in dairy cows (Benchaar et al., 2008b; van Zijderveld et al., 2011; Yang et al., 2007) except a decrease in ammonia-N that was reported in sheep (Klevenhusen et al., 2011); although the doses of active ingredients in these studies were much greater than in the present study. To our knowledge, this is the first study reporting rumen fermentation data in vivo with a CIN and GAR combination.

\subsection{Performance, feeding behavior, and blood parameters}

It is important to note that the majority of in vivo literature addresses the use of EO either separately or in blends of EO that differ from that used herein. Therefore, caution should be taken when extrapolating conclusions between the current study and prior research. Benchaar et al. (2008b) evaluated the effects of supplementing $1 \mathrm{~g} / \mathrm{d}$ of CIN to lactating cows and reported no effects on milk production and composition. Yang et al. (2007) studied the effect of supplementing $5 \mathrm{~g} / \mathrm{d}$ of GAR, and in this case no effects on milk yield and composition, feed intake, rumen fermentation were observed. Nevertheless, in both studies, the EO doses used were much greater than the ones tested herein. Several studies have evaluated dose responses of EO in vitro (Busquet et al., 2006; Castillejos et al., 2006) and in vivo (Tager and Krause, 2011; Wall et al., 2014) and have provided indications for optimal inclusion doses of EO in the diets of lactating cows. These studies have also illustrated that excessive EO doses may lead to negative effects on performance.

In the current study, in terms of milk yield, there was a three-way interaction $(\mathrm{P}<0.05)$ among treatment, parity, and days on treatment (Fig. 2). This interaction was mainly due to the fact that after $15 \mathrm{~d}$ on treatment, multiparous cows on EO produced more milk ( $32.5 \pm 1.17 \mathrm{~kg} / \mathrm{d})$ than multiparous cows on $\operatorname{CON}(29.7 \pm 1.17 \mathrm{~kg} / \mathrm{d})$; whereas there were no differences between treatments for primiparous cows (Fig. 2). Therefore, these results suggested that an adaptation period of 2 weeks is needed to obtain an increase in milk yield in adult cows. This response is in agreement with Guozhong et al. (2010) who reported an increased in milk production in animals fed NE 300 at the same dose compared with control ( $37.4 \mathrm{~kg} / \mathrm{d} v s$. 
$35.7 \mathrm{~kg} / \mathrm{d}$, respectively), considering also an adaptation period of 15 days. Nevertheless, Kamel et al. (2009) and Serbester et al. (2012) did not observed any change in milk yield using the same additive and at the same concentration. Previous in vitro studies conducted with dual flow continuous cultures and EO have also reported that a certain amount of time is needed for the adaptation of rumen microflora to the fermentation conditions and presence of feed additives (Busquet et al., 2005; Cardozo et al., 2004).

By combining the results from experiments 1 and 2, it could be hypothesized that the increase in milk production could be a consequence of an increased energy supply as a result of a modification of rumen fermentation towards less methane production. Unfortunately, this hypothesis could not be confirmed with the rumen fermentation data resulted from experiment 2 (because methane was not measured). Furthermore, in vitro fermentation experiments do not always represent what occurs in vivo (Calsamiglia et al., 2007; Hristov et al., 2012); however, our hypothesis could be reinforced by Busquet et al. $(2005,2006)$ who also reported that the addition of CIN and GAR, separately and in a continuous culture, altered microbial fermentation. These authors observed that CIN and GAR affected the acetate-to-propionate ratio and butyrate levels in rumen fluid (decreasing and increasing, respectively), and GAR and its main components also decreased $\mathrm{CH}_{4}$ production.

The positive milk response to treatment observed in multiparous, but not in primiparous cows, was expected. Primiparous animals are still growing and divert substantial amounts of energy to skeletal growth (Hoffman and Funk, 1992), and it could be hypothesized that they used the extra energy provided by the additive for growth and not for milk production. Unfortunately, we did not monitor BW change in this experiment to validate this hypothesis. Most of the studies involving EO in dairy cows have not reported increases in milk yield (Benchaar et al., 2007; Tassoul and Shaver, 2009; Serbester et al., 2012) and little published evidence exists showing increases in milk production (Kung et al., 2008; Guozhong et al., 2010; Wall et al., 2014).

No changes in milk composition were observed in the current study. This finding is in agreement with other studies (Tager and Krause, 2011; Serbester et al., 2012; Flores et al., 2013). Nonetheless, some literature involving other EO blends have reported changes in milk protein (Spanghero et al., 2009; Wall et al., 2014) or fat (Santos et al., 2010) contents. Our findings with respect to milk urea nitrogen contrasted with the results of Kamel et al. (2009) and Guozhong et al. (2010). These authors administered the same combination of CIN and GAR and at the same dose as in the current study, and reported a reduction in milk urea nitrogen in treated animals compared with CON. The inconsistency between our findings and those from Kamel et al. (2009) and Guozhong et al. (2010) could be attributed to different feeding regimes (concentrate-based diet vs forage-based diet and/or medium vs high CP content in the diet; respectively), and also to the duration of the studies ( 1 vs 2-3 months). No change in milk SCC was found herein; this is in contradiction with results obtained by Kamel et al. (2009) and Guozhong et al. (2010), who reported a reduction of this parameter when supplementing EO. The lack of response in SCC in the current study could be due to the relative low basal levels in both groups. Ananda Baskaran et al. (2009) reported that trans-CIN reduced the growth of some mastitis-related bacteria to undetectable levels on day 12 of an in vitro experiment.

Dry matter intake was not affected by NE300 supplementation. The effect of EO on DMI in lactating dairy cows is not consistent. Some studies have shown potential effect of EO to increase feed intake (Kung et al., 2008; Wall et al., 2014); others have reported the contrary (Tassoul and Shaver, 2009), and others (Benchaar et al., 2006, 2007; Tager and Krause, 2011) have reported no changes in DMI, as also observed herein. Focusing only on CIN and GAR (components of NE300), Benchaar et al. (2008b) did not report differences in DMI when $1 \mathrm{~g}$ CIN/d was administrated to lactating cows and similar results were reported by Chaves et al. (2008) when administering CIN at $200 \mathrm{mg} / \mathrm{kg}$ of DMI in barley- or corn-based diet of lambs. However, some studies have also reported a reduction of DMI when feeding CIN to dairy cows (Busquet et al., 2003) and feeding a combination of CIN and eugenol in beef cattle (Cardozo et al., 2006). However, in both cases, the administered doses of CIN were much greater than those used herein. Busquet et al. (2003) and Yang et al. (2007) reported that feeding GAR at 2.4 and $5 \mathrm{~g} / \mathrm{d}$ (respectively) to lactating dairy cows had no effects on DMI. It is not clear how these compounds modify feed intake, but it could be hypothesized that probably some of these compounds may alter palatability and in turn influence DMI. However, no changes in DMI were expected in the current study due to the low inclusion level and the type of encapsulation of the commercial product used.

Due to an increase in milk yield (in multiparous cows) and a numerical decrease in DMI, feed efficiency was numerically greater $(P=0.11)$ with NE300. Results regarding feed efficiency and EO are inconsistent in the literature. Some studies involving other plant extracts and EO (Tassoul and Shaver, 2009; Tekippe et al., 2011; Hristov et al., 2013) have reported increases in feed efficiency, but others report no differences (Yang et al., 2007; Kung et al., 2008). Differences may be due to stage of lactation of doses used. Further investigation is needed, especially focusing on multiparous cows and long-term studies with different stages of lactation to more appropriate characterize potential effects of EO on efficiency responses.

A small number of studies have reported the effect of plant extracts or EO on blood parameters in dairy cows (Tassoul and Shaver, 2009; Serbester et al., 2012). In the current study, blood metabolites (glucose, insulin, and their ratio) were unaffected by treatment, indicating that NE300 did not affect general glucose metabolism. However, Serbester et al. (2012) reported an effect of NE300 at the same dose as the one used herein on serum metabolites in early-lactation dairy cows. They described that NE300 increased blood insulin concentrations, and tended to decrease serum total cholesterol concentrations, and increased blood NEFA concentrations. However, the study of Serbester et al. (2012) was conducted under heat stress conditions, which were likely to affect serum metabolites in a different fashion than observed herein. Cinnamaldehyde has been shown to be efficacious for the treatment of diabetes in a number of diabetic animal models by inducing an increase in 
plasma insulin and decreasing plasma glucose concentrations (Subash et al., 2007). The potential effect and mode of action of this additive on blood metabolites needs to be confirmed with further research.

\section{Conclusions}

Results of this study indicate that NE300 could modify rumen fermentation and, as a consequence, foster increases in milk yield in multiparous cows after an adaptation period of 15 days. However, further investigation over long-term periods should be conducted to assess the mode of action of this product.

\section{Conflict of interest}

The authors state that they have no conflict of interest.

\section{Acknowledgement}

This research was partially funded by Novus Int. Inc., St Charles, MO.

\section{References}

Association of Official Analytical Chemists, 1990. Official Methods of Analysis, 15th edition. AOAC, Arlington, VA, USA.

Association of Official Analytical Chemists. AOAC, 1999. Official Methods of Analysis, 16th edition. AOAC International, Gaithersburg, MD, USA.

Ananda Baskaran, S., Kazmer, G.W., Hinckley, L., Andrew, S.M., Venkitanarayanan, K., 2009. Antibacterial effect of plant-derived antimicrobials on major bacterial mastitis pathogens in vitro. J. Dairy Sci. 92, 1423-1429.

Bach, A., Iglesias, C., Busto, I., 2004. A computerized system for monitoring feeding behavior and individual feed intake of dairy cattle. J. Dairy Sci. 87, 4207-4209.

Bach, A., Iglesias, C., Devant, M., 2007. Daily rumen pH pattern of loose-housed dairy cattle as affected by feeding pattern and live yeast supplementation. Anim. Feed Sci. Technol. 136, 146-153.

Benchaar, C., Petit, H.V., Berthiaume, R., Ouellet, D.R., Chiquette, J., 2003. Effects of essential oil supplement on ruminal fermentation, rumen microbial populations and in sacco degradation of dry matter and nitrogen in the rumen of lactating dairy cows. Can. J. Anim. Sci. 83, 637 (Abstr.).

Benchaar, C., Petit, H.V., Berthiaume, R., Whyte, T.D., Chouinard, P.Y., 2006. Effects of addition of essential oils and monensin premix on digestion, ruminal fermentation, milk production, and milk composition in dairy cows. J. Dairy Sci. 89, 4352-4364.

Benchaar, C., Petit, H.V., Berthiaume, R., Ouellet, D.R., Chiquette, J., Chouinard, P.Y., 2007. Effects of essential oils on digestion, ruminal fermentation, rumen microbial populations, milk production, and milk composition in dairy cows fed alfalfa silage or corn silage. J. Dairy Sci. 90, 886-897.

Benchaar, C., Calsamiglia, S., Chaves, A.V., Fraser, G.R., Colombatto, D., McAllister, T.A., Beauchemin, K.A., 2008a. A review of plant-derived essential oils in ruminant nutrition and production. Anim. Feed Sci. Technol. 145, 209-228.

Benchaar, C., McAllister, T.A., Chouinard, P.Y., 2008b. Digestion, ruminal fermentation, ciliate protozoal populations, and milk production from dairy cows fed cinnamaldehyde, quebracho condensed tannin, or Yucca schidigera saponin extracts. J. Dairy Sci. 91, 4765-4777.

Burrin, J.M., Price, C.P., 1985. Measurement of blood glucose. Ann. Clin. Biochem. 22, 327-342.

Busquet, M., Calsamiglia, S., Ferret, A., Kamel, C., 2003. Efecto del extracto de ajo y/o cinamaldehído sobre la producción, composición y residuos en vacas de alta producción. ITEA Vol-Extra 24, 756-758.

Busquet, M., Calsamiglia, S., Ferret, A., Carro, M.D., Kamel, C., 2005. Effect of garlic oil and four of its compounds on rumen microbial fermentation. J. Dairy Sci. 88, 4393-4404.

Busquet, M., Calsamiglia, S., Ferret, A., Kamel, C., 2006. Plant extracts affect in vitro rumen microbial fermentation. J. Dairy Sci. 89, $761-771$.

Calsamiglia, S., Busquet, M., Cardozo, P.W., Castillejos, L., Ferret, A., 2007. Invited review: essential oils as modifiers of rumen microbial fermentation. J. Dairy Sci. 90, 2580-2595.

Cardozo, P.W., Calsamiglia, S., Ferret, A., Kamel, C., 2004. Effects of natural plant extracts on ruminal protein degradation and fermentation profiles in continuous culture. J. Anim. Sci. 82, 3230-3236.

Cardozo, P.W., Calsamiglia, S., Ferret, A., Kamel, C., 2005. Screening for the effects of natural plant extracts at different pH on in vitro rumen microbial fermentation of a high-concentrate diet for beef cattle. J. Anim. Sci. 83, 2572-2579.

Cardozo, P.W., Calsamiglia, S., Ferret, A., Kamel, C., 2006. Effects of alfalfa extract, anise, capsicum, and a mixture of cinnamaldehyde and eugenol on ruminal fermentation and protein degradation in beef heifers fed a high-concentrate diet. J. Anim. Sci. 84, 2801-2808.

Castillejos, L., Calsamiglia, S., Ferret, A., Losa, R., 2005. Effects of a specific blend of essential oil compounds and the type of diet on rumen microbial fermentation and nutrient flow from a continuous culture system. Anim. Feed Sci. Technol. 119, 9-41.

Castillejos, L., Calsamiglia, S., Ferret, A., 2006. Effect of essential oil active compounds on rumen microbial fermentation and nutrient flow in in vitro systems. J. Dairy Sci. 89, 2649-2658.

Cavini, S., Bravo, D., Calsamiglia, S., Rodriguez, M., Ferret, A., Schroeder, S., 2009. Synergy of cinnamaldehyde, eugenol and garlic for reduction of methane production in vitro. J. Anim. Sci. 87, 374 (Abstr.).

Chaney, A.L., Marbach, E.P., 1962. Modified reagents for determination of urea and ammonia. Clin. Chem. 8, 130-132.

Chao, S.C., Young, D.G., Oberg, C.J., 2000. Screening for inhibitory activity of essential oils on selected bacteria, fungi and viruses. J. Essent. Oil Res. 12, 639-649.

Chaves, A.V., Stanford, K., Dugan, M.E.R., Gibson, L.L., McAllister, T.A., Van Herk, F., Benchaar, C., 2008. Effects of cinnamaldehyde, garlic and juniper berry essential oils on rumen fermentation, blood metabolites, growth performance, and carcass characteristics of growing lambs. Livest. Sci. 117, 215-224.

Demeyer, D.I., Van Nevel, C.J., 1975. Methanogenesis, an integrated part of carbohydrate fermentation, and its control. In: McDonald, I.W., Warner, A.C.I. (Eds.), Digestion and Metabolism in the Ruminant. Univ. New England Publishing Unit, Armidale, N.S.W., Australia.

Demeyer, D.I., 1991. Quantitative aspects of microbial metabolism in the rumen and hindgut. In: Jouany, J.P. (Ed.), Rumen Microbial Metabolism and Ruminant Digestion. INRA Editions, Paris, France, pp. 217-237.

Ferme, D., Banjac, M., Calsamiglia, S., Busquet, M., Kamel, C., Avgustin, G., 2004. The effects of plant extracts on microbial community structure in a rumen-simulating continuous-culture system as revealed by molecular profiling. Folia Microbiol. (Praha) 49, 151-155.

Flores, A.J., Garciarena, A.D., Hernández Vieyra, J.M., Beauchemin, K.A., Colombatto, D., 2013. Effects of specific essential oil compounds on the ruminal environment, milk production and milk composition of lactating dairy cows at pasture. Anim. Feed Sci. Technol. 186, 20-26.

Goering, M.K., Van Soest, P.J., 1970. Forage fiber analysis (apparatus, reagents, procedures and some applications). In: In: Agricultural Handbook, No. 379 Agricultural Research Services. USDA, Washington, DC.

Hoffman, P.C., Funk, D.A., 1992. Applied dynamics of dairy replacement growth and management. J. Dairy Sci. 75, 2504-2516. 
Hristov, A.N., Lee, C., Hristova, R., Huhtanen, P., Firkins, J.L., 2012. A meta-analysis of variability in continuous-culture ruminal fermentation and digestibility data. J. Dairy Sci. 95, 5299-5307.

Hristov, A.N., Lee, C., Cassidy, T., Heyler, K., Tekippe, J.A., Varga, G.A., Corl, B., Brand, R.C., 2013. Effect of Origanum vulgare L. leaves on rumen fermentation production, and milk fatty acid composition in lactating dairy cows. J. Dairy Sci. 96, 1189-1202.

Jouany, J.P., 1982. Volatile fatty acids and alcohol determination in digestive contents silage juices, bacterial cultures and anaerobic fermentation contents. Sci. Alim. 2, 131-144.

Kamel, C., Greathead, H.M.R., Cardozo, P.W., 2009. Effects of an encapsulated combination of cinnamaldehyde and garlic oil on early and late lactating Red Simmental dairy cows. J. Anim. Sci. 87, 375 (Abstr.).

Kim, E.T., Kim, C.-H., Min, K.-S., Lee, S.S., 2012. Effects of plant extracts on microbial population, methane emission and ruminal fermentation characteristics in in vitro. Asian-Australas. J. Anim. Sci. 25, 806-811.

Klevenhusen, F., Zeitz, J.O., Duval, S., Kreuzer, M., Soliva, C.R., 2011. Garlic oil and its principal component diallyl disulfide fail to mitigate methane, but improve digestibility in sheep. Anim. Feed Sci. Technol. 166-167, 356-363.

Kongmun, P., Wanapat, M., Navanukraw, C., 2010. Effect of coconut oil and garlic powder on in vitro fermentation using gas production technique. Liv. Sci. 134, 38-44.

Kung Jr., L., Williams, P., Schmidt, R.J., Hu, W., 2008. A blend of essential plant oils used as an additive to alter silage fermentation or used as a feed additive for lactating dairy cows. J. Dairy Sci. 91, 4793-4800.

Macheboeuf, D., Morgavi, D.P., Papon, Y., Mousset, J.-L., Arturo-Schaan, M., 2008. Dose-response effects of essential oils on in vitro fermentation activity of the rumen microbial population. Anim. Feed Sci. Technol. 145, 335-350.

Martínez, M.E., Ranilla, M.J., Tejido, M.L., Ramos, S., Carro, M.D., 2010. The effect of the diet fed to donor sheep on in vitro methane production and ruminal fermentation of diets of variable composition. Anim. Feed Sci. Technol. 158, 126-135.

Mateos, I., Ranilla, M.J., Tejido, M.L., Saro, C., Kamel, C., Carro, M.D., 2013. The influence of diet type (dairy versus intensive fattening) on the effectiveness of garlic oil and cinnamaldehyde to manipulate in vitro ruminal fermentation and methane production. Anim. Prod. Sci. $53,299-307$.

McIntosh, F.M., Williams, P., Losa, R., Wallace, R.J., Beever, D.A., Newbold, C.J., 2003. Effects of essential oils on ruminal microorganisms and their protein metabolism. Appl. Environ. Microbiol. 69, 5011-5014.

Molero, R., Ibars, A., Calsamiglia, S., Ferret, A., Losa, R., 2004. Effects of a specific blend of essential oil compounds on dry matter and crude protein degradability in heifers fed diets with different forage to concentrate ratios. Anim. Feed Sci. Technol. 114, 91-104.

Newbold, C.J., McIntosh, F.M., Williams, P., Losa, R., Wallace, R.J., 2004. Effects of a specific blend of essential oil compounds on rumen fermentation. Anim. Feed Sci. Technol. 114, 105-112.

Santos, M.B., Robinson, P.H., Williams, P., Losa, R., 2010. Effects of addition of an essential oil complex to the diet of lactating dairy cows on whole tract digestion of nutrients and productive performance. Anim. Feed Sci. Technol. 157, 64-71.

Serbester, U., Çınar, M., Ceyhan, A., Erdem, H., Görgülü, M., Kutlu, H.R., Baykal Çelik, L., Yücelt, Ö., Cardozo, P.W., 2012. Effect of essential oil combination on performance, milk composition, blood parameters and pregnancy rate in early lactating dairy cows during heat exposure. J. Anim. Plant Sci. 22, $556-563$.

Soliva, C.R., Amelchanka, S.L., Duval, S.M., Kreuzer, M., 2011. Ruminal methane inhibition potential of various pure compounds in comparison with garlic oil as determined with a rumen simulation technique (Rusitec). Brit. J. Nutr. 106, 114-122.

Spanghero, M., Robinson, P.H., Zanfi, C., Fabbro, E., 2009. Effect of increasing doses of microencapsulated blend of essential oils on performance of lactating primiparous dairy cows. Anim. Feed Sci. Technol. 153, 153-157.

Subash, B.P., Prabuseenivasan, S., Ignacimuthu, S., 2007. Cinnamaldehye - a potential antidiabetic agent. Phytomedicine 14, 15-22.

Tager, L.R., Krause, K.M., 2011. Effects of essential oils on rumen fermentation, milk production, and feeding behavior in lactating dairy cows. J. Dairy Sci. $94,2455-2464$.

Tassoul, M.D., Shaver, R.D., 2009. Effect of a mixture of supplemental dietary plant essential oils on performance of periparturient and early lactation dairy cows. J. Dairy Sci. 92, 1734-1740.

Tekippe, J.A., Hristov, A.N., Heyler, K.S., Cassidy, T.W., Zheljazkov, V.D., Ferreira, J.F.S., Karnati, S.K., Varga, G.A., 2011. Rumen fermentation and production effects of Origanum vulgare L. leaves in lactating dairy cows. J. Dairy Sci. 94, 5065-5079.

Van Soest, P.J., Robertson, J.B., Lewis, B.I., 1991. Methods for dietary fiber, neutral detergent fiber and non-starch polysaccharide in relation to animal nutrition. J. Dairy Sci. 74, 3583-3597.

van Zijderveld, S.M., Dijkstra, J., Perdok, H.B., Newbold, J.R., Gerrits, W.J., 2011. Dietary inclusion of diallyl disulfide, yucca powder, calcium fumarate, an extruded linseed product, or medium-chain fatty acids does not affect methane production in lactating dairy cows. J. Dairy Sci. 94, 3094-3104.

Wall, E.H., Doane, P.H., Donkin, S.S., Bravo, D., 2014. The effects of supplementation with a blend of cinnamaldehyde and eugenol on feed intake and milk production of dairy cows. J. Dairy Sci. 97, 5709-5717.

Yang, W.Z., Benchaar, C., Ametaj, B.N., Chaves, A.V., He, M.L., McAllister, T.A., 2007. Effects of garlic and juniper berry essential oils on ruminal fermentation and on the site and extent of digestion in lactating cows. J. Dairy Sci. 90, 5671-5681. 